\title{
PERANCANGAN SISTEM BASIS DATA ONLINE MONITORING KUALITAS AIR DI SUNGAI CILIWUNG
}

Online Monitoring Database System Design for Water Quality of Ciliwung River

\author{
Oleh: \\ Satmoko Yudo \\ Pusat Teknologi Lingkungan, BPPT
}

\begin{abstract}
Abstrak
Pertumbuhan penduduk di kota Jakarta yang terus meningkat setiap tahun, hal ini mengakibatkan dampak pencemaran lingkungan khususnya pencemaran sungai Ciliwung terus bertambah. Saat ini berbagai usaha telah dilakukan dalam hal pencegahan pencemaran terhadap sungai Ciliwung. Salah satu upaya untuk mengendalikan pencemaran yang terjadi di Sungai Ciliwung adalah melakukan pemantauan kualitas air di sungai Ciliwung. Pemantauan ini dilakukan secara real-time dan online, dimana data kualitas air dikirim ke pusat data dan dianalisa menjadi informasi yang dapat ditampilkan setiap saat dan dimana saja melalui internet. Bila ada polutan yang masuk ke sungai sehingga sungai tercemar berat dalam suatu waktu tertentu, pemerintah atau pihak yang berwenang yang mengelola sungai dapat melakukan tindakan tanggap pengendalian pencemaran. Untuk mendukung sistem pemantauan secara realtime dan online berjalan dengan baik diperlukan sistem manajemen basis data (database) untuk menyimpan data kualitas air setiap saat dengan baik dan terintegrasi.
\end{abstract}

Kata kunci : pencemaran sungai, pemantauan kualitas air secara online, Sungai Ciliwung, perancangan basis data.

\begin{abstract}
Population growth in the Jakarta city that continues to rise each year, this has resulted in environmental pollution, especially pollution of the Ciliwung river continues to grow. Nowadays various attempts have been made in terms of prevention of pollution of the river Ciliwung. One of the efforts to control pollution in the river Ciliwung is monitoring the quality of water in rivers and creeks Ciliwung. This monitoring is done in real-time and online, where the water quality data sent to data centers and analyzed into information that can be displayed at any time and anywhere through the Internet. If there are pollutants that enter the river so heavilly polluted in certain time, the government or the authorities that manages the river can take action to control pollution. To support online monitoring system running well required database management system (DBMS) for storing water quality data at any time and integrated well.
\end{abstract}

Keywords : river pollution, water quality monitoring online, Ciliwung river, design database.

\section{PENDAHULUAN}

Sungai Ciliwung adalah salah satu dari 13 sungai yang ada di wilayah DKI Jakarta dan paling banyak melewati wilayah pemukiman. Sejalan dengan pertumbuhan penduduk yang terus meningkat menyebabkan daerah permukiman di wilayah Jabodetabek terus berkembang. Hal ini juga mengakibatkan terjadi perubahan dan alih fungsi lahan disepanjang daerah aliran sungai (DAS) kali Ciliwung, yang semula merupakan daerah resapan air hujan (infiltrasi) berubah menjadi lahan permukiman dan kegiatan industri (1). Akibat dari perubahan ini, jumlah air limbah yang dibuang ke Kali Ciliwung juga terus meningkat dari waktu kewaktu. Dengan terus bertambahnya jumlah air limbah, sehingga kualitas air Kali Ciliwung terus menurun bahkan saat ini dikelompokkan sudah tercemar berat (2).

Upaya untuk mengendalikan pencemaran, salah satunya adalah pemantauan kualitas air baik yang akan masuk ke sungai, atau di lokasi aliran sungai. Pemantauan ini perlu dilakukan secara terus menerus dengan cara menganalisis kualitas air yang masuk atau yang berada pada aliran sungai secara periodik. Bila ada polutan yang masuk ke sungai atau kondisi sungai tercemar ekstrim dalam suatu waktu tertentu, pemerintah atau pihak yang berwenang untuk mengelola sungai dapat melakukan tindakan pengendalian pencemaran. 
Untuk melakukan pemantauan kualitas air sungai, cara konvensional yang saat ini dilakukan adalah mengambil sampel di lokas pemantauan, membawa ke laboratorium dan menganalisakannya. Banyak sekali kendala yang dihadapi terkait pemantauan rutin kualitas air sungai secara konvensional ini, diantaranya adalah jarak dari lokasi ke laboratorium analisa kualitas air yang cukup jauh, kemacetan lalu lintas, dan juga resiko bahaya saat pengambilan sampel langsung di lokasi sungai. Kendala lain yang cukup signifikan yakni biaya analisa sampel yang cukup mahal sehingga untuk melakukan pemantauan rutin di banyak titik di aliran sungai, anggaran yang diperlukan sangat besar.

Upaya yang perlu dilakukan untuk mengatasi kendala tersebut dan mengefisienkan pemantauan kualitas air, adalah dengan menerapkan sistem online monitoring kualitas air di beberapa lokasi pemantauan baik di lokasi sumber pencemar, maupun di lokasi aliran sungai itu sendiri. Pusat Teknologi Lingkungan, Badan Pengkajian dan Penerapan Teknologi telah meneliti dan mengembangkan sistem pemantauan kualitas air secara online sejak tahun 1997. Beberapa lembaga lain baik swasta maupun pemerintah telah menerapkan teknologi ini untuk memantau kualitas air baik di sungai, danau maupun di laut.

\section{TUJUAN DAN SASARAN}

Tujuan dalam kegiatan ini adalah merancang sistem basis data online monitoring kualitas air di sungai Ciliwung.

Sasaran yang diperoleh adalah mendapatkan data hasil pemantauan kualitas air di sungai Ciliwung untuk pengendalian pencemaran lingkungan.

\section{PERANCANGAN SISTEM PERANGKAT LUNAK ONLINE MONITORING}

Rancangan sistem perangkat lunak untuk online monitoring dibagi ke dalam dua jenis rancangan. Yang pertama adalah rancangan sistem software aplikasi SMS gateway yang digunakan untuk mengendalikan data logger dari pusat data menggunakan perintah-perintah yang telah didefinisikan dan kemudian dikirimkan melalui SMS (Short Message Services) dengan komunikasi GSM (Global System for Mobile). Perangkat lunak ini dapat juga digunakan untuk mengambil data yang berada dalam internet memori pada data logger. Rancangan yang kedua adalah rancangan sistem basis data untuk menyimpan dan menelusuri data-data hasil pengukuran online.

Perangkat lunak basis data ini menerima data yang dikirimkan dari setiap sensor melalui GSM modem berupa SMS (Short Message Service). SMS tersebut dibaca oleh SMS gateway kemudian dirubah menjadi format basis data.

Perangkat lunak aplikasi SMS gateway bertugas membaca SMS yang diterima oleh GSM Modem, kemudian menginterpretasikan isi SMS serta nomor pengirim SMS. Apabila nomor pengirim bukan berasal dari nomor yang sudah terdaftar di basis data, yaitu nomor-nomor telepon pengguna atau nomor telepon stasiun pemantauan, maka isi SMS akan diabaikan dan dihapus dari memori di GSM Modem. Akan tetapi kalau SMS berasal dari nomor yang terdaftar, maka SMS akan dianalisa, apakah SMS yang masuk berupa data dari stasiun pemantauan atau berupa permintaan informasi dari penggguna. Data yang dikirim dari stasiun pemantauan langsung diterjemahkan oleh aplikasi SMS dan disimpan dalam format basis data. Tampilan data-data ini bisa disajikan dalam bentuk grafik atau tabel angka. Sistem perangkat lunak basis data ini dirancang menggunakan sistem basis data terstruktur yang lebih dikenal dengan nama RDBMS (Relational Database Management System) (3).

Selain data reguler yang diterima oleh aplikasi SMS, stasiun pemantauan dapat juga mengirim data pada saat-saat kritis sebagai peringatan dini (Early Warning System), yaitu pada kondisi dimana terjadi kenaikan ekstrim nilai $\mathrm{pH}$, temperatur, penurunan kadar oksigen (Dissolve Oxygen/DO) dan lainnya. Data-data ini selain disimpan dalam basis data juga dapat memberikan sinyal bagi aplikasi SMS untuk melakukan antisipasi, misalnya mengirim SMS ke nomor-nomor Hand phone orang-orang tertentu yang memiliki tanggung jawab terhadap pengelolaan sistem ini serta pihak berwenang dalam mengatasi terjadinya pencemaran. $\mathrm{Hal}$ ini sangat penting dalam menunjang sistem kontrol terhadap sistem monitoring untuk pengendalian pencemaran lingkungan(4). Data yang dikirimkan oleh unit data logger melalui GSM Modem ke komputer pusat data akan disimpan ke dalam sistem basis data, sehingga penelusuran data monitoring yang telah disimpan dapat dilakukan dengan cepat dan mudah.

\section{METODOLOGI PERANCANGAN BASIS DATA}

Metodologi rancangan sistem basis data yang digunakan dibagi menjadi dua bagian utama, yaitu: metode analisis dan metode perancangan.

\subsection{Metode Analisis}

Melakukan analisis terhadap hasil
pengumpulan data sekunder dan identifikasi
permasalahan yang berhubungan dengan sistem
yang akan dibuat serta menentukan kebutuhan
informasi apa saja yang diperlukan.




\subsection{Metode Perancangan}

Metode yang digunakan dalam perancangan basis data ${ }^{(5)}$ berdasarkan pada :
a. Perancangan basis data konseptual,
b. Perancangan basis data logikal,
c. Perancangan basis data fisikal,
d. Perancangan aplikasi,
e. Perancangan layar.

\section{ANALISA KEBUTUHAN INFORMASI PENGGUNA (USER INFORMATION RECUIREMENT)}

Dari hasil pengumpulan kebutuhan informasi pengguna, maka setelah di analisa diperoleh kebutuhan informasi untuk sistem informasi online monitoring kualitas air adalah sbb.:

Tabel 1 : Kebutuhan Informasi Pengguna (Hoffer et al 2002).

\begin{tabular}{|l|l|}
\hline \multicolumn{1}{|c|}{ Entity } & \multicolumn{1}{|c|}{ Deskrpisi } \\
\hline Stasiun & $\begin{array}{l}\text { Secara umum Stasiun peman- } \\
\text { tauan/monitoring dapat diartikan } \\
\text { sebagai suatu lokasi/tempat untuk } \\
\text { aktivitas dalam pengambilan contoh air } \\
\text { atau udara secara berkala ataupun }\end{array}$ \\
& $\begin{array}{l}\text { secara terus menerus untuk keperluan } \\
\text { menentukan tingkat pencemaran/ } \\
\text { radiasi. Aktivitas pemantauan adalah } \\
\text { merupakan salah satu tugas pengawasan }\end{array}$ \\
& $\begin{array}{l}\text { lingkungan dalam mendeteksi dan } \\
\text { mengevaluasi apabila terjadi perubahan } \\
\text { kualitas suatu lingkungan. }\end{array}$ \\
\hline Data & $\begin{array}{l}\text { Data pengukuran adalah suatu data } \\
\text { kegiatan untuk mendapatkan informasi }\end{array}$ \\
secara kuantitatif. Hasil dari pengukuran \\
dapat berupa informasi-informasi atau \\
data yang dinyatakan dalam bentuk \\
angka ataupun uraian yang sangat \\
berguna dalam pengambilan keputusan, \\
oleh karena itu mutu informasi haruslah \\
akurat.
\end{tabular}

\section{PERANCANGAN SISTEM BASIS DATA}

Menurut Connolly dan Begg (2010, p470485) tahapan dalam perancangan sistem basis data dibagi ke dalam 3 tahap utama yaitu :

- Tahap perancangan basis data konseptual,

- Tahap perancangan basis data logikal dan

- Tahap perancangan basis data fisikal.

dimana masing-masing dari tahapan tersebut memiliki langkah-langkah sendiri.

\subsection{Merancang Basis data Konseptual}

Pada tahap ini, perancangan dilakukan berdasarkan analisis langsung pada sistem yang akan dibangun. Dengan analisis tersebut maka dapat mempermudah perancangan konseptual data untuk menentukan entitas, atribut dan hubungan setiap entitas yang akan digunakan dalam perancangan sistem basis data.

\subsubsection{Identifikasi Tipe Entitas}

Langkah berikutnya adalah melakukan identifikasi tipe-tipe entitas utama yang dibutuhkan terkait sistem basis data yang akan dibuat. Terdapat 3 (tiga) entitas seperti pada tabel berikut ini.

Tabel 2 : Entitas Sistem Online Monitoring.

\begin{tabular}{|l|l|l|l|}
\hline $\begin{array}{l}\text { Nama } \\
\text { Entitas }\end{array}$ & Uraian & Alias & Kejadian \\
\hline $\begin{array}{l}\text { Mtasiun } \\
\text { Monitoring }\end{array}$ & $\begin{array}{l}\text { Tempat untuk } \\
\text { memonitor } \\
\text { kualitas air di } \\
\text { pinggir sungai }\end{array}$ & Stasiun & $\begin{array}{l}\text { Setiap } \\
\text { stasiun } \\
\text { memonitor } \\
\text { kualitas air } \\
\text { sungai }\end{array}$ \\
\hline Data & $\begin{array}{l}\text { Data-data } \\
\text { kualitas air } \\
\text { beberapa } \\
\text { parameter } \\
\text { yang diukur } \\
\text { sesuai periode } \\
\text { waktu }\end{array}$ & Data & $\begin{array}{l}\text { Setiap data } \\
\text { kualitas air } \\
\text { dari setiap } \\
\text { paramter } \\
\text { yang diukur }\end{array}$ \\
& $\begin{array}{l}\text { Orang yang } \\
\text { mengelola } \\
\text { dan mencatat } \\
\text { data } \\
\text { pengukuran } \\
\text { dari stasiun } \\
\text { monitoring }\end{array}$ & User & $\begin{array}{l}\text { Setiap user } \\
\text { mengelola } \\
\text { data } \\
\text { pengukuran } \\
\text { dan stasiun } \\
\text { monitoring }\end{array}$ \\
\hline
\end{tabular}

\subsubsection{Identifikasi Hubungan Antar Entitas}

Kemudian melakukan identifikasi hubunganhubungan yang penting dan yang terdapat di tiaptiap entitas. Langkah-langkah penting dalam identifikasi tipe relational adalah : membuat ERD (Entity Relationship Diagram), dan menentukan pembatas multiplicity dari tipe relational. Gambar 1 adalah diagram hubungan antar Entitas yang ada.

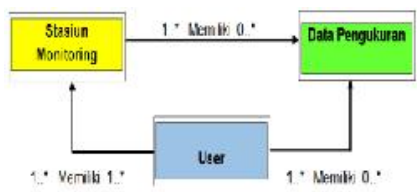

Gambar 1 : Identifikasi Hubungan Antar Entitas Dalam Sistem Online Monitoring. 


\subsubsection{Membuat Entity Relationship Diagram (ERD) dengan Primary Key}

Diagram relasi ketiga entitas basis data pemantauan kualitas air adalah seperti pada gambar di bawah ini.

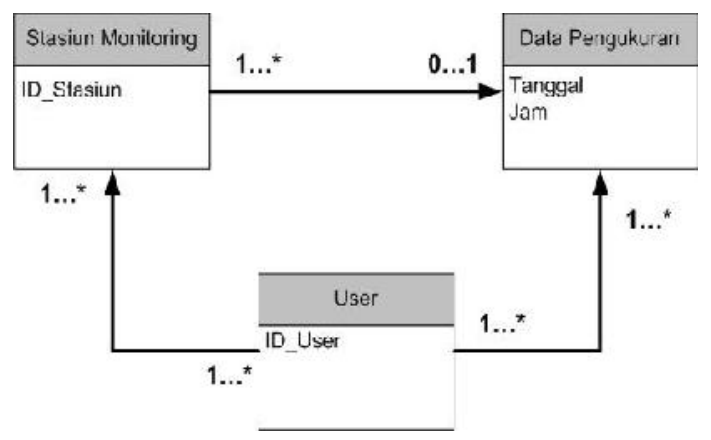

Gambar 2 : ERD dengan Primary Key.

\subsubsection{Menggunakan Jalur Transaksi}

Pendekatan kedua untuk memvalidasi data model terhadap transaksi yang dibutuhkan direpresentasikan oleh jalur yang diambil pada ERD seperti dijelaskan pada gambar di bawah ini.

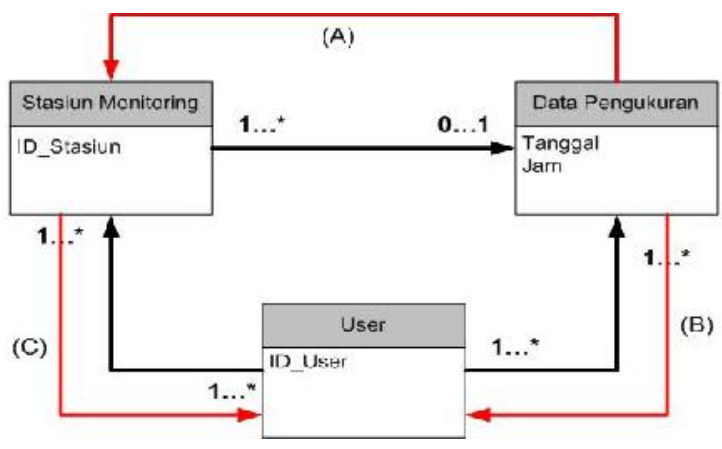

Gambar 3 : Jalur Transaksi Dalam Sistem Online Monitoring.

\subsection{Merancang Basis data Logikal}

Menurut Connolly dan Begg (2010, p490460) langkah-langkah membangun rancangan basis data logikal adalah membangun data model logikal dengan tahapan sebagai berikut :

\subsubsection{Tipe Hubungan Binary One-to-Many (1..*)}

Untuk setiap tipe relasi binary One-to-many $\left(1 . .^{*}\right)$, entitas pada 'sisi satu' dari relasi disebut sebagai entitas parent, dan entitas pada 'sisi banyak' disebut dengan entitas child. Untuk merepsesentasikan relasi ini, dengan meletakkan salinan atribut primary key dari entitas parent ke dalam relasi yang merepresentasikan entitas child sebagai foreign key.

\subsubsection{Tipe Hubungan Binary One-to-One (1..1)}

Membuat relasi untuk merepresentasikan sebuah hubungan $1 . .1$ sedikit lebih kompleks karena cardinality tidak bisa digunakan untuk membantu menentukan entitas parent atau entitas child dalam hubungan tersebut. Sebagai gantinya, kita menggunakan partipation constrasmallint untuk membantu menentukan representasi hubungan tersebut. Ada 3 cara untuk menentukan relasi menggunakan participation constrasmallint cara tersebut antara lain :

- Mandatory participation pada kedua entitas dari hubungan 1..1

- Mandatory participation pada satu entitas dari hubungan $1 . .1$

- Optional participation pada kedua entitas dari hubungan $1 . .1$

Namun, pada data model konseptual yang dibangun, hanya terdapat mandatory satu entitas dari hubungan 1..1 oleh karena itu entitas parent dan child dapat ditentukan dengan participant constrasmallint. Entitas yang memiliki participant mandatory menjadi entitas child. Kemudian salinan primary key dari parent di letakkan di entitas child sehingga menjadi foreign key.

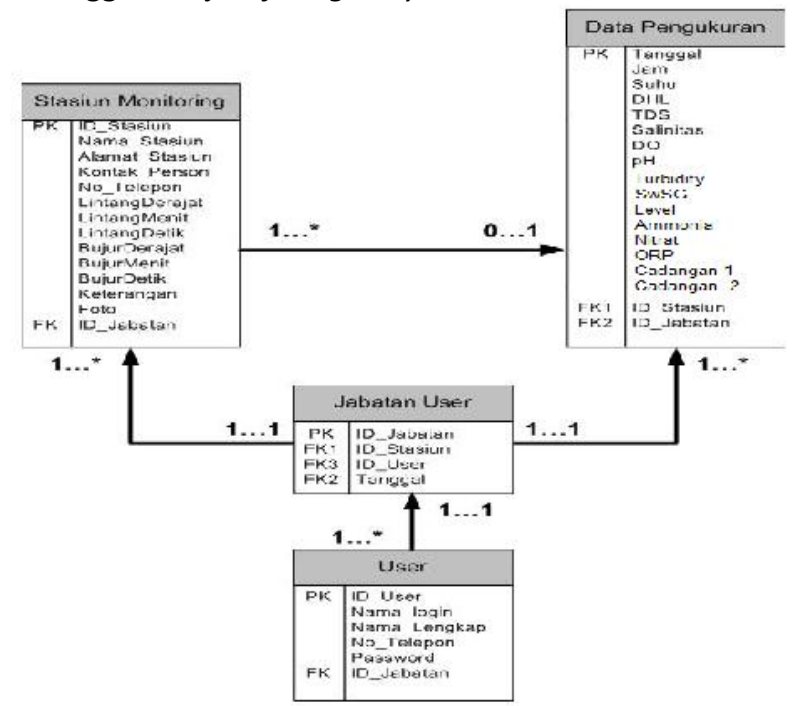

Gambar 4 : Diagram Validasi Transaksi user pada ERD setelah normalisasi.

\subsection{Merancang Basis data Fisikal \\ 6.3.1. Menerjemahkan Data Model Global Logikal Untuk DBMS}

Tujuan dari tahap ini untuk menghasilkan sebuah skema basis data relasional dari data model global logikal yang bisa di implementasikan pada Database Management System (DBMS) tujuan. Tahap ini terdiri dari 3 langkah : 


\section{- Merancang relasi dasar}

Tahapan ini adalah untuk menentukan bagaimana merepresentasikan relasi dasar yang telah di identifikasikan pada data model global logikal di DBMS tujuan. Untuk merepresentasikan design dari relasi dasar, kita menggunakan perluasan dari DBDL (Database Design Language) untuk menentukan domain, default value, dan null indicator.

\section{Stasiun Monitoring}

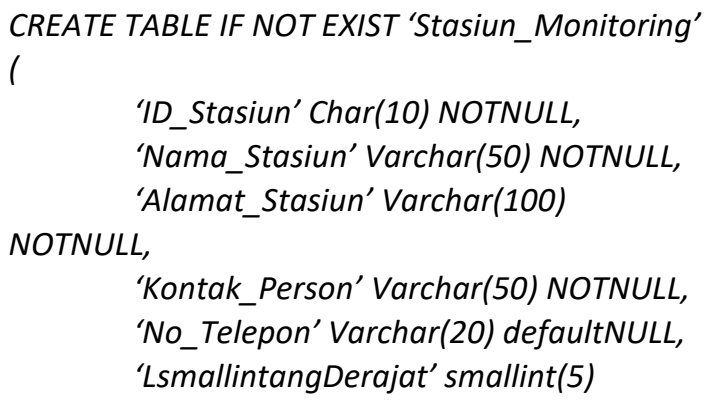

'Param3, smallint (5), NOTNULL., 'ID_Stasiun' Char(10) NOTNULL,

'ID_Jabatan' char(10), NOTNULL, PRIMARY KEY (Tanggal, Jam)

FOREIGN KEY ('ID_Stasiun'), PRIMARY KEY 'Stasiun_Monitoring', ON UPDATE CASCADE ON DELETE CASCADE

FOREIGN KEY ('ID_Jabatan') REFERENCES 'Jabatan_User' ON UPDATE CASCADE ON DELETE CASCADE

);

\section{Jabatan User}

CREATE TABLE IF NOT EXIST 'Jabatan_User'

(

'ID_Jabatan' char(10) NOTNULL, 'Nama_Jabatan' varchar(20) NOTNULL, 'ID_User' char(10) NOTNULL, 'ID_Stasiun' char(10) NOTNULL, 'Tanggal' date NOTNULL,

PRIMARY KEY (ID_Jabatan)

FOREIGN KEY ('ID_Stasiun'), PRIMARY KEY 'Stasiun_Monitoring', ON UPDATE CASCADE ON DELETE CASCADE

FOREIGN KEY ('ID_User') REFERENCES 'User' ON UPDATE CASCADE ON DELETE CASCADE

FOREIGN KEY ('Tanggal', 'jam') REFERENCES 'Data_Pengukuran' ON UPDATE CASCADE ON DELETE CASCADE

);

\section{User}

\section{CREATE TABLE IF NOT EXIST 'User’}

(

'ID_User' char(10) NOTNULL, 'Nama_Login' varchar(20) NOTNULL, 'Nama_Lengkap' varchar(50) NOTNULL, 'ID_Jabatan' char(10) NOTNULL, 'No_Telepon' varchar(20) defaultNULL, 'Password' varchar(15) NOTNULL, PRIMARY KEY (ID_User) FOREIGN KEY ('ID_Jabatan') REFERENCES 'Jabatan_User' ON UPDATE CASCADE ON DELETE CASCADE );

\subsubsection{Menganalisa Transaksi}

Transaksi yang terdapat dalam software online monitoring yaitu :

- Mencatat data stasiun monitoring

- Mencatat data pengukuran

- Mencatat data user

- Mencatat data jabatan user 
Tabel 3 : Analisa Transaksi Dengan Entitas Data Model Yang Sudah Ada.

\begin{tabular}{l|l|l|l|l|l|l|l|l|l|l|l|l|l|l|l|l}
\hline $\begin{array}{l}\text { TRAN } \\
\text { SAKSI }\end{array}$ & \multicolumn{5}{c|}{ A } & \multicolumn{5}{c|}{ B } & \multicolumn{5}{c|}{ C } & \multicolumn{4}{c|}{ D } \\
\hline Relasi & $\mathrm{I}$ & $\mathrm{R}$ & $\mathrm{U}$ & $\mathrm{D}$ & $\mathrm{I}$ & $\mathrm{R}$ & $\mathrm{U}$ & $\mathrm{D}$ & $\mathrm{I}$ & $\mathrm{R}$ & $\mathrm{U}$ & $\mathrm{D}$ & $\mathrm{I}$ & $\mathrm{R}$ & $\mathrm{U}$ & $\mathrm{D}$ \\
\hline $\begin{array}{l}\text { Stasiun } \\
\text { Monitor } \\
\text { ing }\end{array}$ & $\mathrm{x}$ & $\mathrm{x}$ & $\mathrm{x}$ & $\mathrm{x}$ & & & & & & & & & & & & \\
\hline $\begin{array}{l}\text { Data } \\
\text { Pengu } \\
\text { kuran }\end{array}$ & & & & & $\mathrm{x}$ & $\mathrm{x}$ & $\mathrm{x}$ & $\mathrm{x}$ & & & & & & & & \\
\hline $\begin{array}{l}\text { Jabatn } \\
\text { User }\end{array}$ & & & & & & & & & $\mathrm{x}$ & $\mathrm{x}$ & $\mathrm{x}$ & $\mathrm{x}$ & & & & \\
\hline \begin{tabular}{l} 
User \\
\hline
\end{tabular} & & & & & & & & & & & & & $\mathrm{x}$ & $\mathrm{x}$ & $\mathrm{x}$ & $\mathrm{x}$ \\
\hline
\end{tabular}

Keterangan :

$\mathrm{I}=$ Insert, $\mathrm{R}=$ Read, $\mathrm{U}=$ Update, $\mathrm{D}=$ Delete

\subsubsection{Memilih Indeks}

Indeks digunakan untuk memudahkan pencarian data, di bawah ini adalah daftar indeks dalam sistem basis data online monitoring kualitas air.

Tabel 4 : Daftar Indeks.

\begin{tabular}{r|l|l}
\hline No & \multicolumn{1}{|c|}{ Entitas } & \multicolumn{1}{|c}{ Nama Indeks } \\
\hline 1 & Stasiun Monitoring & KodeStasiunMonitoring \\
\hline 2 & Data Pengukuran & KodeDataPengukuran \\
\hline 3 & Jabatan User & IDJabatan \\
\hline 4 & User & IDUser \\
\hline
\end{tabular}

\subsubsection{Memperkirakan Kebutuhan Disk-Space (Estimating Disk Space Requirement)}

Dalam menentukan berapa besar kebutuhan disk-space dari sistem basis data online monitoring kualitas air, maka akan di estimasi penggunaan diskspace dari setiap entitas/tabel.

\section{- Entitas Stasiun Monitoring}

Tabel 5 : Estimasi Penggunaan Disk Entitas Stasiun Monitoring.

\begin{tabular}{l|l|l|c}
\hline \multicolumn{1}{c|}{ ENTITAS } & NAMA ATRIBUT & \multicolumn{1}{|c|}{ TIPE DATA } & $\begin{array}{c}\text { TOTAL } \\
\text { BYTE }\end{array}$ \\
\hline $\begin{array}{l}\text { Stasiun } \\
\text { Monitoring }\end{array}$ & ID_Stasiun & Char(10) & 10 \\
\hline & Nama_Stasiun & Varchar(50) & 51 \\
\hline & Alamat_Stasiun & Varchar(100) & 101 \\
\hline & Kontak_Person & Varchar(50) & 51 \\
\hline & No_Telepon & Varchar(20) & 21 \\
\hline & LsmallintangDerajat & smallint(5) & 5 \\
\hline & LsmallintangMenit & smallint(5) & 5 \\
\hline & LsmallintangDetik & smallint(5) & 5 \\
\hline & Bujurderajat & smallint(5) & 5 \\
\hline & BujurMenit & smallint(5) & 5 \\
\hline
\end{tabular}

\begin{tabular}{r|l|l|c}
\hline & BujurDetik & smallint(5) & 5 \\
\hline & Keterangan & Varchar(100) & 101 \\
\hline & Foto & Bitmap image & 100 \\
\hline & & Total & 465 \\
\hline & & 1 Tahun & 0,14 \\
& & MB \\
\hline
\end{tabular}

Kapasitas penggunaan disk oleh entitas Stasiun Monitoring setiap baris (row/record) adalah sebesar 465 bytes.

> Diperkirakan terdapat 25 Stasiun Monitoring, sehingga data baris (row/record) sebesar 25 baris/record.

$>$ Untuk menghitung jumlah baris yang dapat terisi pada $8 \mathrm{~K}$ pada halaman data (data page) dgn perhitungan:

8060 / bytes per row = rows per page, maka diperoleh $8060 / 465=17$ baris per halaman.

$>$ Untuk menghitung jumlah halaman data yang dibutuhkan berdasarkan estimasi baris tabel, maka perhitungannya:

Jumlah estimasi baris / baris per halaman = kebutuhan halaman data. Atau:

$25 / 17=3,6$ halaman data yang dibutuhkan.

Kalikan nilai ini dengan 8192 untuk menjumlahkan kebutuhan bytes untuk tabel Stasiun Monitoring.

$8192 *$ halaman data yang dibutuhkan $=$ total bytes.

$8192 * 3,6=29.491,2$ bytes.

$>$ Diperkirakan dalam 1 tahun penambahan Stasiun Monitoring 5 bh, maka total kebutuhan disk space untuk entitas Stasiun Monitoring:

$5 * 29.491,2=147.456$ bytes.

$>$ Total KB : $147.456 / 1024=144 \mathrm{~KB}$

$>$ Total MB : $144,4 / 1021=0,14 \mathrm{MB}$

\section{- Entitas Data Pengukuran}

Tabel 6 : Estimasi Penggunaan Disk Entitas Data Pengukuran.

\begin{tabular}{l|l|l|c}
\hline ENTITAS & \multicolumn{1}{|c|}{$\begin{array}{c}\text { NAMA } \\
\text { ATRIBUT }\end{array}$} & TIPE DATA & $\begin{array}{c}\text { TOTAL } \\
\text { BYTE }\end{array}$ \\
\hline $\begin{array}{l}\text { Data } \\
\text { Pengukuran }\end{array}$ & Tanggal & date & 8 \\
\hline & Jam & time & 8 \\
\hline & Suhu & smallint(5) & 5 \\
\hline & DHL & smallint(5) & 5 \\
\hline & TDS & smallint(5) & 5 \\
\hline & Salinitas & smallint(5) & 5 \\
\hline & DO & smallint(5) & 5 \\
\hline & pH & smallint(5) & 5 \\
\hline & Turbidity & smallint(5) & 5 \\
\hline & SwSG & smallint(5) & 5 \\
\hline
\end{tabular}




\begin{tabular}{c|l|l|c}
\hline & Depth & smallint(5) & 5 \\
\hline & Ammonia & smallint(5) & 5 \\
\hline & Nitrat & smallint(5) & 5 \\
\hline & ORP & smallint(5) & 5 \\
\hline & Param1 & smallint(5) & 5 \\
\hline & Param2 & smallint(5) & 5 \\
\hline & Param3 & smallint(5) & 5 \\
\hline & ID_Stasiun & Char(5) & 5 \\
\hline & ID_Jabatan & Char(5) & 5 \\
\hline & & Total & 96 \\
\hline & & 1 Tahun & 4.860 \\
& & MB \\
\hline
\end{tabular}

Kapasitas penggunaan disk oleh entitas Data Pengukuran setiap baris (row/record) adalah sebesar 96 bytes.

$>$ Diperkirakan dalam 1 hari terdapat ((24jam*60mnt)/20menit) 72 baris (row/record) untuk Data Pengukuran.

Untuk menghitung jumlah baris yang dapat terisi pada $8 \mathrm{~K}$ pada halaman data (data page) dgn perhitungan:

8060 / bytes per row = rows per page,

maka diperoleh $8060 / 96=84$ baris per halaman.

> Untuk menghitung jumlah halaman data yang dibutuhkan berdasarkan estimasi baris tabel, maka perhitungannya:

Jumlah estimasi baris / baris per halaman = kebutuhan halaman data. Atau:

$72 / 84=0,8$ halaman data yang dibutuhkan.

Kalikan nilai ini dengan 8192 untuk menjumlahkan kebutuhan bytes untuk tabel Data Pengukuran.

$8192 *$ halaman data yang dibutuhkan $=$ total bytes.

$8192 * 0,8=6.553,6$ bytes.

$>$ Diperkirakan dalam 1 tahun penambahan record Data Pengukuran ((360 hari*24jam*60menit)/20menit) untuk 1 Stasiun Monitoring, maka total kebutuhan disk space untuk entitas Data Pengukuran :

((360 hari*24jam*60menit)/20menit)

$6.553,6=169.869 .312$ bytes.

$>$ Selama 1 tahun terdapat 30 Stasiun Monitoring maka:

30 Stasiun Monitoring * 169.869.312 = 5.096 .079 .360 bytes.

> Total KB : 5.096.079.360 /1024=4.976.640 KB

> Total MB : 4.976.640/1024=4.860 MB.

$>$ Total GB $: 4.860 / 1024=4,7$ GB.
Tabel 7 : Estimasi Penggunaan Disk Entitas User.

\begin{tabular}{|c|c|c|c|}
\hline ENTITAS & NAMA ATRIBUT & TIPE DATA & $\begin{array}{l}\text { TOTAL } \\
\text { BYTE }\end{array}$ \\
\hline \multirow[t]{4}{*}{$\begin{array}{l}\text { Jabatan } \\
\text { User }\end{array}$} & ID_Jabatan & Char(5) & 5 \\
\hline & ID_Stasiun & Char(5) & 5 \\
\hline & ID_User & Char(5) & 5 \\
\hline & Tanggal & Date & 8 \\
\hline \multirow[t]{6}{*}{ User } & ID_User & Char(5) & 5 \\
\hline & Nama_login & $\operatorname{VarChar}(20)$ & 20 \\
\hline & Nama_Lengkap & VarChar(100) & 100 \\
\hline & No_Telepon & $\operatorname{VarChar}(20)$ & 20 \\
\hline & Password & $\operatorname{VarChar}(20)$ & 20 \\
\hline & ID_Jabatan & Char(5) & 5 \\
\hline \multicolumn{3}{|r|}{ Total } & 193 \\
\hline \multicolumn{3}{|r|}{1 Tahun } & $0,33 \mathrm{MB}$ \\
\hline
\end{tabular}

Kapasitas penggunaan disk oleh entitas User setiap baris (row/record) adalah sebesar 193 bytes.

> Diperkirakan terdapat 12 baris (row/record) untuk User dalam Basis data ini.

Untuk menghitung jumlah baris yang dapat terisi pada $8 \mathrm{~K}$ pada halaman data (data page) dgn perhitungan:

8060 / bytes per row = rows per page,

maka diperoleh 8060/193 = 84 baris per halaman.

> Untuk menghitung jumlah halaman data yang dibutuhkan berdasarkan estimasi baris tabel, maka perhitungannya:

Jumlah estimasi baris $/$ baris per halaman $=$ kebutuhan halaman data. Atau:

$12 / 84=0,14$ halaman data yang dibutuhkan.

Kalikan nilai ini dengan 8192 untuk menjumlahkan kebutuhan bytes untuk tabel User.

$8192 *$ halaman data yang dibutuhkan $=$ total bytes. $8192 * 0,14=1.170,3$ bytes.

$>$ Diperkirakan dalam 1 tahun penambahan record Data User tergantung kepada penambahan Stasiun Monitoring,maka total kebutuhan disk space untuk entitas User:

(12 user $\times 25$ stasiun monitoring) $* 1.170,3=$ 351.090 bytes.

Total KB : 351.090/1024 $=342,8 \mathrm{~KB}$

Total MB : 342,8 /1024=0,33 MB. 
Tabel 8 : Estimasi Penggunaan Disk Total Entitas.

\begin{tabular}{l|c|c}
\hline \multicolumn{1}{c|}{ ENTITAS } & $\begin{array}{c}\text { TOTAL Bytes } \\
\text { PERHARI }\end{array}$ & $\begin{array}{c}\text { TOTAL MegaBytes } \\
\text { PERTAHUN }\end{array}$ \\
\hline $\begin{array}{l}\text { Stasiun } \\
\text { Monitoring }\end{array}$ & $29.491,2$ & 0,14 \\
\hline Data Pengukuran & $6.553,6$ & 4.860 \\
\hline User & $1.170,3$ & 0,33 \\
\hline TOTAL & $37.215,1$ & $4.860,47$ \\
\hline
\end{tabular}

Penggunaan Disk Space dalam 1 hari :

37.215,1 KB

Penggunaan Disk Space 1 tahun :

4.860,5 MB atau 4,7 GB

Penggunaan Disk Space 5 tahun :

$5 * 4,7 \mathrm{~GB}=23,5 \mathrm{~GB}$

\subsubsection{Merancang Mekanisme Keamanan}

Tahap ini bertujuan untuk merancang keamanan bagi basis data sesuai dengan user yang mengaksesnya. Terdapat dua tipe keamaan basis data yaitu keamanan sistem dan keamanan data.

Keamanan sistem terdiri dari akses dan penggunaan dari basis data pada level sistem. Dalam perancangan sistem ini, kami mengharuskan pengguna untuk login agar dapat mengakses data yang diperlukan. User yang tidak login tidak dapat memiliki hak untuk mengakses basis data.

User yang login diberikan hak akses sesuai dengan jabatannya. Hak akses tersebut diberikan kepada antara lain :

- Administrator (Admin),

- Kepala Bidang/Bagian,

- Operator data input

- Guest (Tamu)

Hak akses tersebut mempunyai batasan untuk mengakses basis data yang akan ditunjukkan pada tabel dibawah :

Tabel 9 : Daftar Hak Akses Setiap User.

\begin{tabular}{l|c|c|c|c|c|c|c|c|c|c|c|c|c|c|c|c}
\hline $\begin{array}{l}\text { Hak } \\
\text { Akses }\end{array}$ & \multicolumn{3}{c}{ A } & \multicolumn{5}{c|}{ B } & \multicolumn{5}{c|}{ C } & \multicolumn{3}{c}{ D } \\
\hline Relasi & $\mathrm{I}$ & $\mathrm{R}$ & $\mathrm{U}$ & $\mathrm{D}$ & $\mathrm{I}$ & $\mathrm{R}$ & $\mathrm{U}$ & $\mathrm{D}$ & $\mathrm{I}$ & $\mathrm{R}$ & $\mathrm{U}$ & $\mathrm{D}$ & $\mathrm{I}$ & $\mathrm{R}$ & $\mathrm{U}$ & $\mathrm{D}$ \\
\hline $\begin{array}{l}\text { Stasiun } \\
\text { Monitor } \\
\text { ing }\end{array}$ & $\mathrm{x}$ & $\mathrm{x}$ & $\mathrm{x}$ & $\mathrm{x}$ & & $\mathrm{x}$ & & & $\mathrm{x}$ & $\mathrm{x}$ & $\mathrm{x}$ & & & $\mathrm{x}$ & & \\
\hline $\begin{array}{l}\text { Data } \\
\text { Penguk } \\
\text { uran }\end{array}$ & $\mathrm{x}$ & $\mathrm{x}$ & $\mathrm{x}$ & $\mathrm{x}$ & & $\mathrm{x}$ & & & $\mathrm{x}$ & $\mathrm{x}$ & $\mathrm{x}$ & & & $\mathrm{x}$ & & \\
\hline User & $\mathrm{x}$ & $\mathrm{x}$ & $\mathrm{x}$ & $\mathrm{x}$ & & $\mathrm{x}$ & & & $\mathrm{x}$ & $\mathrm{x}$ & $\mathrm{x}$ & & & & & \\
\hline
\end{tabular}

Keterangan :

$\mathbf{I}=$ Insert, $\mathbf{R}=$ Read, $\mathbf{U}=$ Update, $\mathbf{D}=$ Delete

\subsection{Perancangan Layar Perangkat Lunak Basis Data}

\section{Online Monitoring}

\subsubsection{Perancangan Aplikasi}

Tujuan adalah merancang small interface yang efektif untuk sistem perangkat lunak. Efektif artinya siap digunakan, dan hasilnya sesuai dg kebutuhan. Kebutuhan disini adalah kebutuhan penggunanya. Pengguna sering menilai sistem dari small interface, bukan dari fungsinya melainkan dari user small interfacenya. Jika desain user small interfacenya yang buruk, maka itu sering jadi alasan untuk tidak menggunakan software. Selain itu small interface yang buruk sebabkan pengguna membuat kesalahan fatal.

Saat ini small interface yang banyak digunakan dalam software adalah GUI (Graphical User Smallinterface).

GUI memberikan keuntungan seperti:

- Mudah dipelajari oleh pengguna yang pengalaman dalam menggunakan komputer cukup minim,

- Berpindah dari satu layar ke layar yang lain tanpa kehilangan informasi dimungkinkan,

- Akses penuh pada layar dengan segera untuk beberapa macam tugas/keperluan.

\subsubsection{Perancangan Struktur Menu Basis data Online Monitoring}

Struktur menu sistem basis data online monitoring menjelaskan tentang susunan menu yang ada dalam perancangan aplikasi sistem software ini. Secara garis besar rancangan struktur menu software ini adalah sebagai berikut ${ }^{(4)}$ :

Login Struktur Menu dibagi dalam 3 yaitu :

- Struktur Menu Administrator Hanya administrator yang dapat login ke dalam Home Monitoring, Home Database, Home Stasiun, Home Regulasi dan Home Pengguna.

- Struktur Menu Operator Hanya operator yang dapat login ke dalam Home Monitoring, Home Database, Home Stasiun dan Home Regulasi.

- Struktur Menu Tamu Tamu hanya dapat ke dalam Home Monitoring, Home Database, dan Home Regulasi.

Gambar 5 berikut ini menjelaskan skema struktur menu utama. 


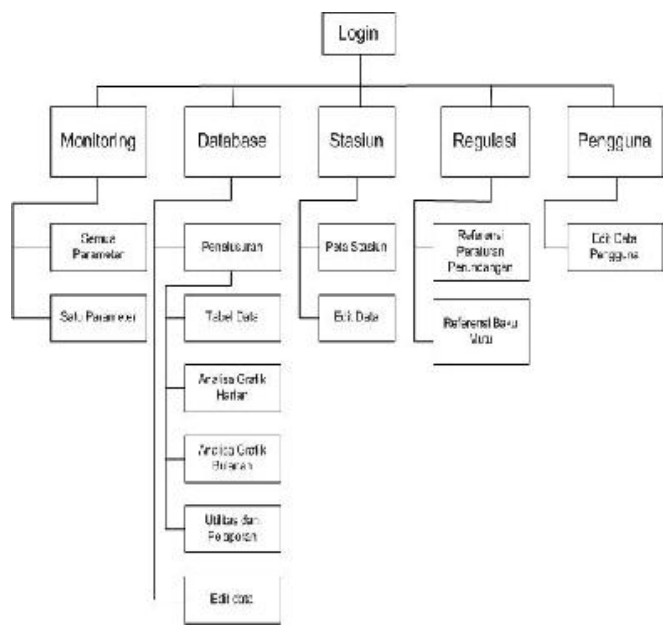

Gambar 5 : Struktur Menu Utama.

\subsubsection{Perancangan Layar Basis data Online Monitoring}

Perancangan layar dilakukan untuk menentukan bentuk/form dari sistem software basis data online monitoring yang akan dibuat. Beberapa contoh rancangan layar yang telah dibuat seperti di bawah ini :

\section{- Layar LOGIN}

Pilih Kode Akses,

Ketik Password,

Ketik Enter $\rightarrow$ Login benar akan masuk ke halaman berikutnya yaitu Menu Utama

Klik Keluar $\rightarrow$ Keluar Sistem

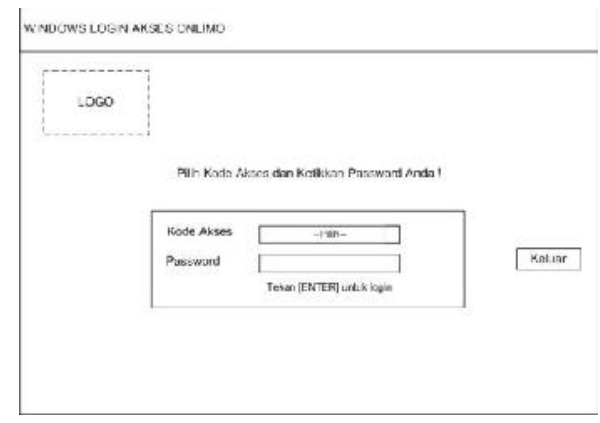

Gambar 6 : Halaman Login.

\section{- Layar Menu Utama}

Klik Monitoring $\rightarrow$ Windows On line Monitoring Kualitas Air

Klik Database $\rightarrow$ Windows Penelusuran Data Online Monitoring

Klik Stasiun $\rightarrow$ Windows Data Stasiun Monitoring Klik Regulasi $\rightarrow$ Windows Regulasi dan Baku Mutu Klik Pengguna $\rightarrow$ Windows Edit Data Pengguna Klik Keluar $\rightarrow$ Halaman Login

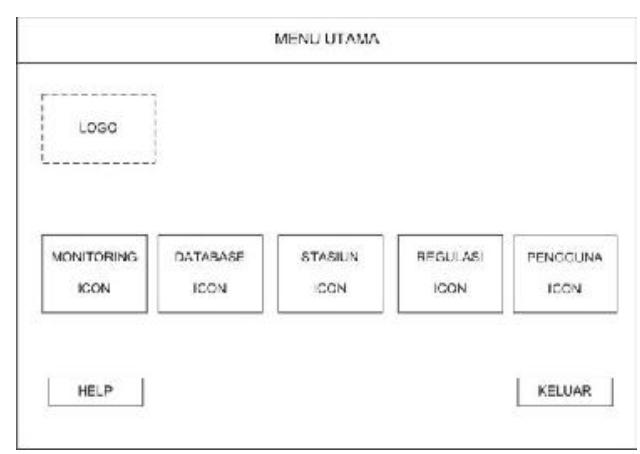

Gambar 7 : Halaman Menu Utama.

- Windows On line Monitoring Kualitas Air 1

Pilih Nama Stasiun

Klik Semua Parameter $\rightarrow$ Grafik 6 parameter (Suhu, Salinitas, DHL, DO, TDS, pH)

Klik Icon selesai $\rightarrow$ Kembali ke Menu Utama

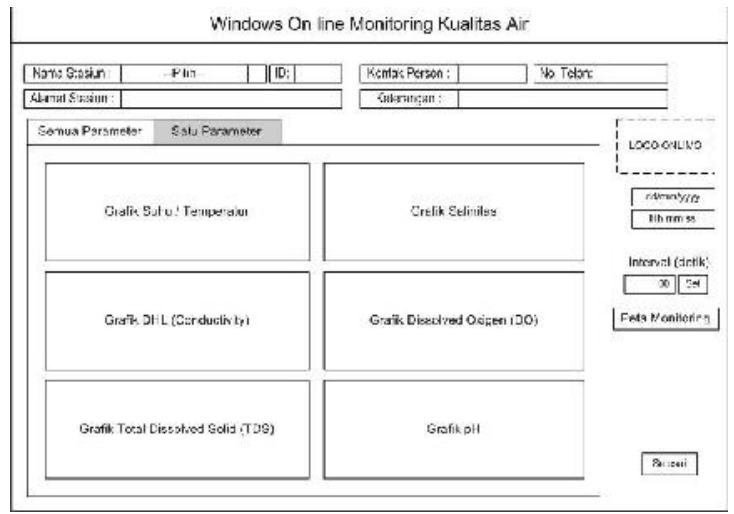

Gambar 8: Halaman Kualitas Air Semua Parameter.

\section{- Windows On line Monitoring Kualitas Air 2}

Klik Satu Parameter Pilih Parameter (Suhu, Salinitas, DHL, DO, TDS, $\mathrm{pH}) \rightarrow$ Grafik 1 parameter

Klik Icon selesai $\rightarrow$ Kembali ke Menu Utama

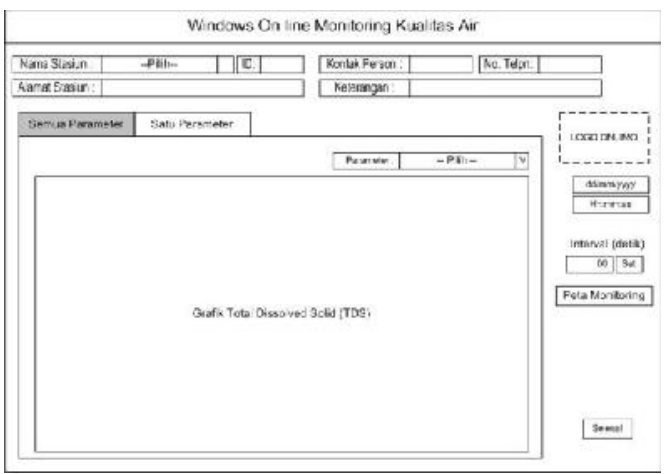

Gambar 9 : Halaman Kualitas Air Salah Satu Parameter. 
- Windows Penelusuran Data Online Monitoring 1

Klik Penelusuran

Pilih Nama Stasiun

Klik Tabel Data $\rightarrow$ Tampilan Database tanggal, jam, Suhu, Salinitas, DHL, DO, TDS, pH Klik Icon selesai $\rightarrow$ Kembali ke Menu Utama

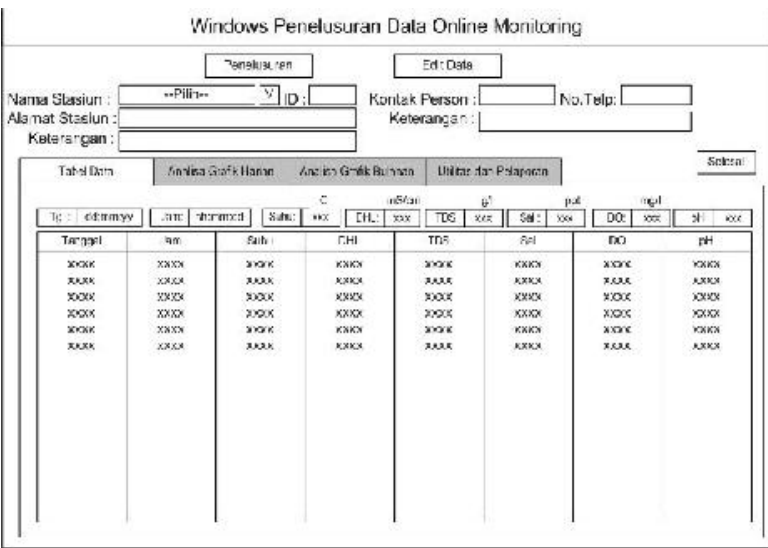

Gambar 10 : Halaman Tabel Data 6 Parameter

- Windows Penelusuran Data Online Monitoring 2

Pilih Nama Stasiun

Klik Analisa Grafik Harian $\rightarrow$ Layar Grafik

Pilih Tahun, Bulan, Tanggal, Jam Mulai, Jam Akhir, dan Parameter $\rightarrow$ Grafik 1 parameter

Klik Icon Laporan Harian $\rightarrow$ Laporan Data Monitoring

Klik Icon Reload/Update $\rightarrow$ Memunculkan grafik Klik Icon selesai $\rightarrow$ Kembali ke Menu Utama

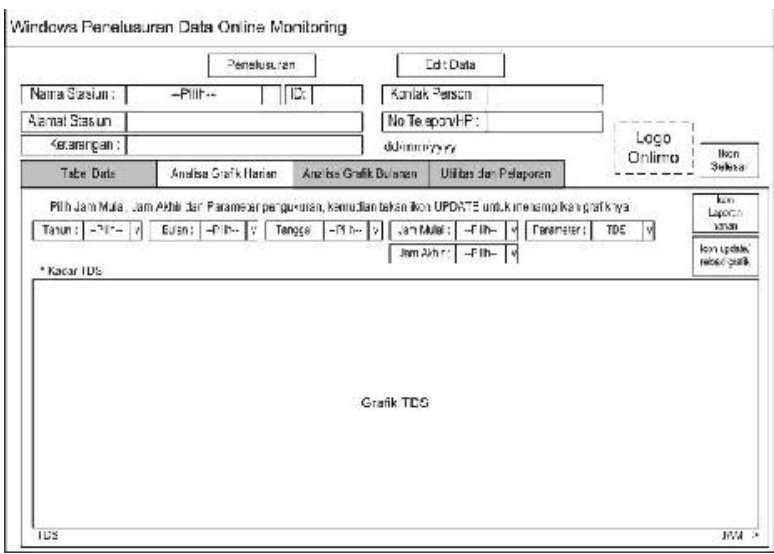

Gambar 11 : Halaman Analisa Grafik Harian.

\section{- Windows Penelusuran Data Online Monitoring 3}

Pilih Nama Stasiun

Klik Analisa Grafik Bulanan $\rightarrow$ Layar Grafik Pilih Tahun, Bulan, dan Parameter $\rightarrow$ Grafik 1 Parameter
Klik Icon Laporan Harian $\rightarrow$ Laporan Data Monitoring

Klik Icon Reload/Update $\rightarrow$ Memunculkan grafik Klik Icon selesai $\rightarrow$ Kembali ke Menu Utama

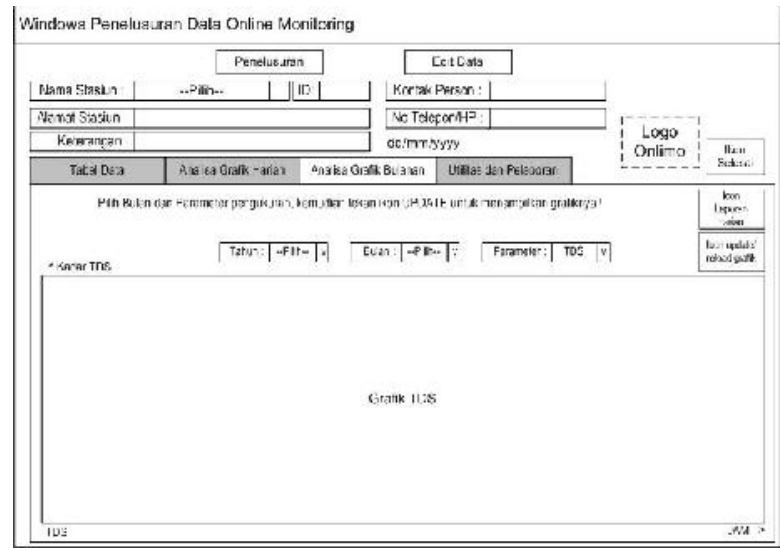

Gambar 12 : Halaman Analisa Grafik Bulanan.

- Windows Penelusuran Data Online Monitoring 4

Pilih Nama Stasiun

Klik Utilitas dan Pelaporan $\rightarrow$ Menu Laporan dan Menu Utilitas

Klik Icon selesai $\rightarrow$ Kembali ke Menu Utama

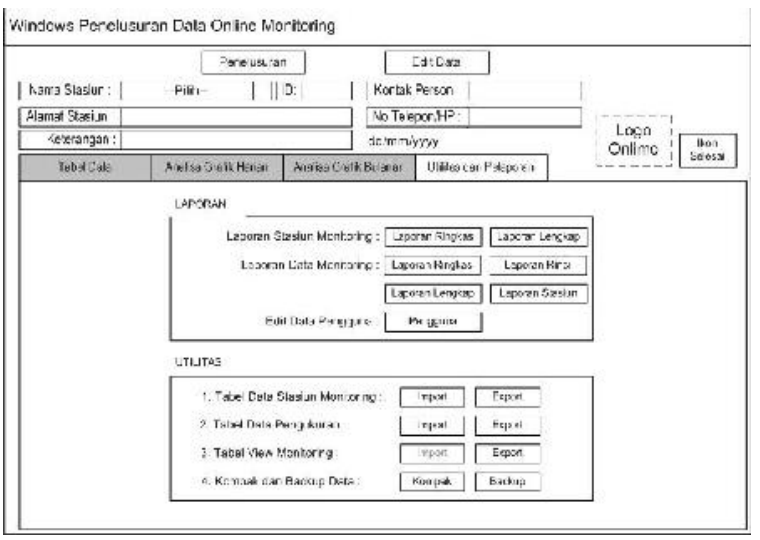

Gambar 13 : Halaman Utilitas dan Pelaporan.

- Windows Penelusuran Data Online Monitoring 5

Klik Edit Data $\rightarrow$ Menu Stasiun dan Menu Kualitas Pilih Stasiun $\rightarrow$ Edit Tanggal dan Jam Ukur, Edit Koordinat, Edit Keterangan

Pilih Kualitas $\rightarrow$ Edit Suhu, Salinitas, DHL, DO, TDS, $\mathrm{pH}$

Klik Icon Simpan Data $\rightarrow$ Data Edited disimpan Klik Icon Laporan Data $\rightarrow$ Laporan Rinci Data Monitoring Kualitas Air

Klik Icon Find Record $\rightarrow$ Halaman find data Klik Icon Hapus Data $\rightarrow$ Menghapus satu atau lebih data monitoring Klik Icon selesai $\rightarrow$ Kembali ke Menu Utama 


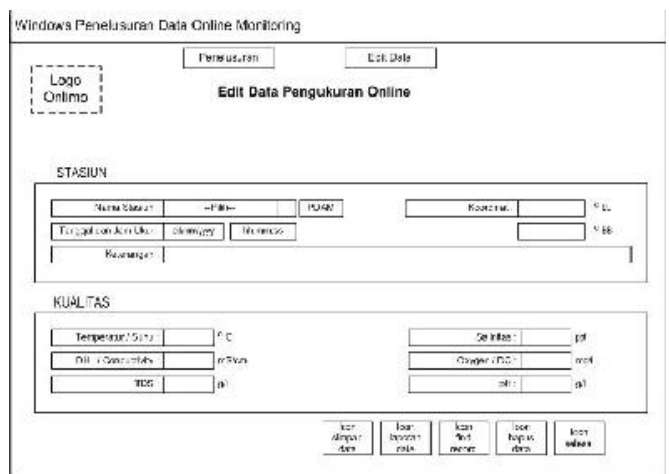

Gambar 14 : Halaman Edit Data Stasiun dan Kualitas.

- Windows Data Stasiun Monitoring 1

Klik Peta Stasiun $\rightarrow$ Peta Lokasi Stasiun Monitoring

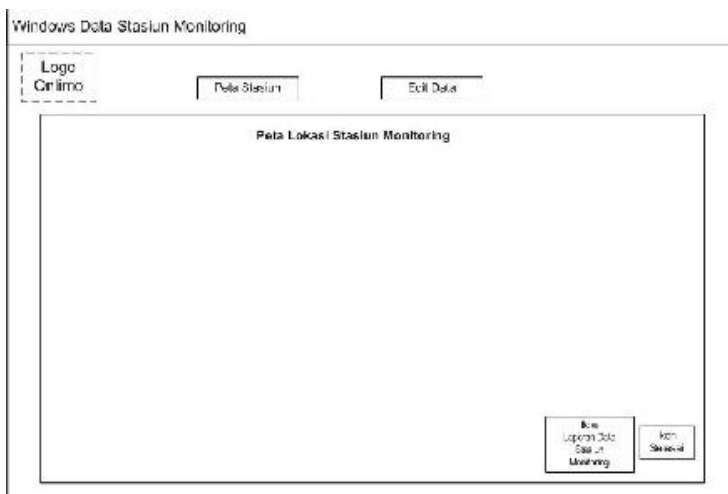

Gambar 15 : Halaman Peta Lokasi Stasiun.

\section{- Windows Data Stasiun Monitoring 2}

Klik Edit Data $\rightarrow$ Edit Data Stasiun Monitoring Klik Tambah Data $\rightarrow$ Input data stasiun Klik Simpan Data $\rightarrow$ Simpan data Stasiun Klik Cari Record Data $\rightarrow$ Halaman find record Klik Laporan Data $\rightarrow$ Laporan data monitoring Klik Hapus Data $\rightarrow$ Hapus satu atau lebih data Klik Icon selesai $\rightarrow$ Kembali ke Menu Utama

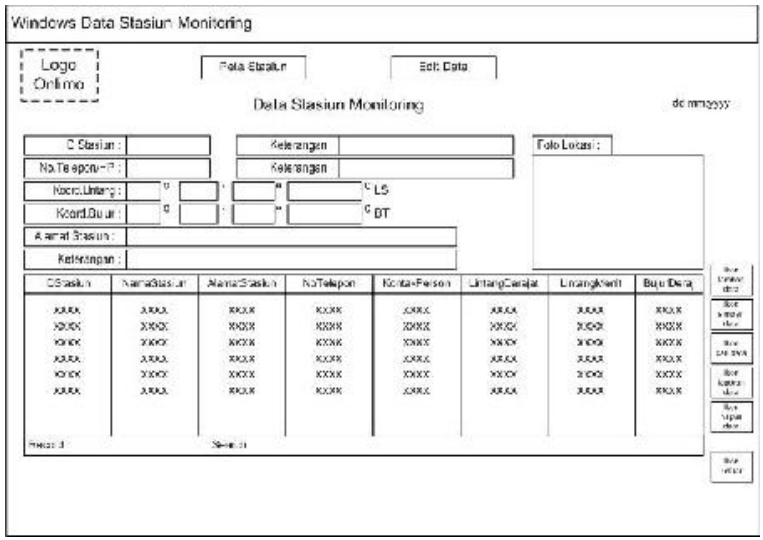

Gambar 16 : Halaman Data Stasiun Monitoring.

\section{- Windows Regulasi dan Baku Mutu 3}

Klik Ikon Buka File $\rightarrow$ Peraturan Perundangan Klik Ikon Golongan A $\rightarrow$ Baku Mutu Kualitas Air Golongan A

Dst.. idem klik Golongan D

Klik Industri Baterei $\rightarrow$ Baku Mutu Limbah Cair Utk Industri Baterei Kering

Dst ....idem klik Industri Tekstil

Klik Icon selesai $\rightarrow$ Kembali ke Menu Utama

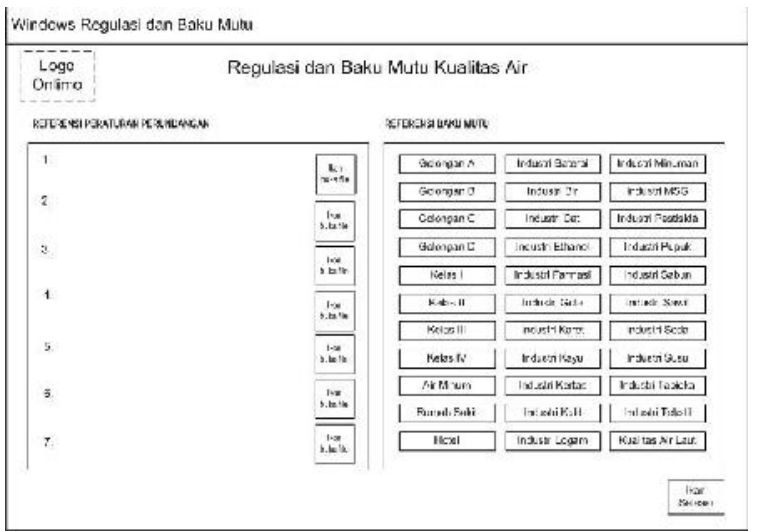

Gambar 17: Halaman Regulasi dan Baku Mutu Kualitas Air.

\section{- Windows Edit Data Pengguna 4}

Klik Ikon Tambah Data $\rightarrow$ Isi Data User Baru Klik Edit Data $\rightarrow$ Edit Data Stasiun Monitoring Klik Tambah Data $\rightarrow$ Input data stasiun Klik Simpan Data $\rightarrow$ Simpan data Stasiun Klik Cari Record Data $\rightarrow$ Halaman find record Klik Laporan Data $\rightarrow$ Laporan data monitoring Klik Hapus Data $\rightarrow$ Hapus satu atau lebih data Klik Icon selesai $\rightarrow$ Kembali ke Menu Utama

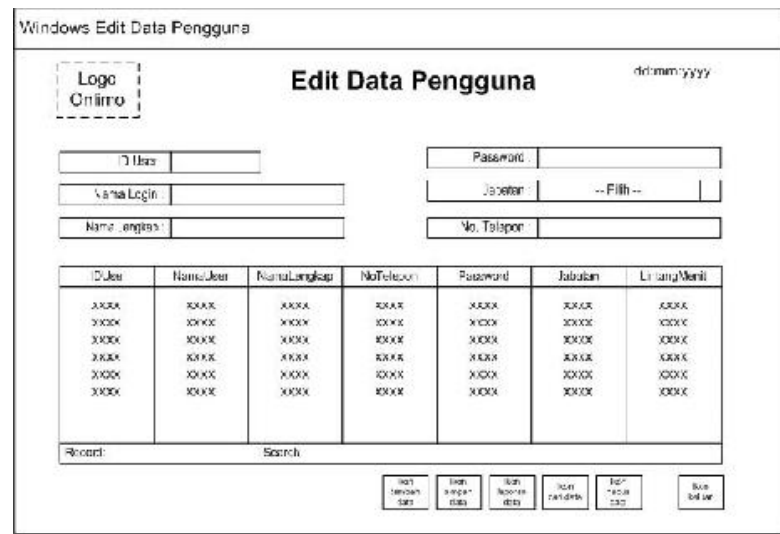

Gambar 18: Halaman Edit Pengguna.

\subsection{State Transition Diagram (STD) Modul Login}

State transition diagram digunakan untuk memberikan deskripsi abstrak tentang perilaku dari 
suatu sistem. Perilaku ini dianalisis dan direpresentasikan dalam serangkaian kejadian, yang dapat terjadi dalam satu atau lebih kemungkinan. Dengan ini setiap diagram biasanya mewakili objek dari satu kelas dan melacak setiap keadaan yang berbeda dari objek melalui sistem.

STD menggambarkan bagaimana kerja sistem melalui kondisi (state) dan kejadian yang menyebabkan kondisi berubah. STD juga menggambarkan aksi yang dilakukan karena kejadian tertentu. State Transition Diagram adalah suatu diagram yang menggambarkan bagaimana suatu proses dihubungkan satu sama lain dalam waktu yang bersamaan .

Berikut ini adalah STD bagi modul Login yang membedakan user menjadi 3 kategori, yaitu administrator, operator dan guest. Software basis data membedakamn status aktifasi menu berdasarkan ketiga kategori pengguna aplikasi ini.

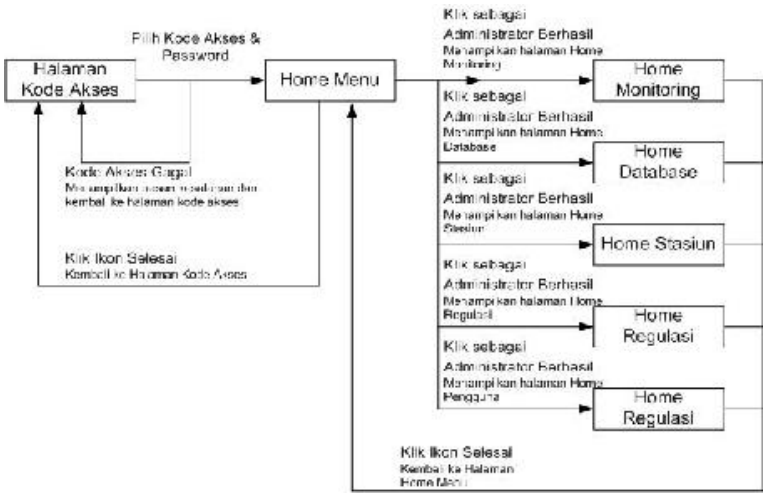

Gambar 19 : STD Login sebagai Administrator.

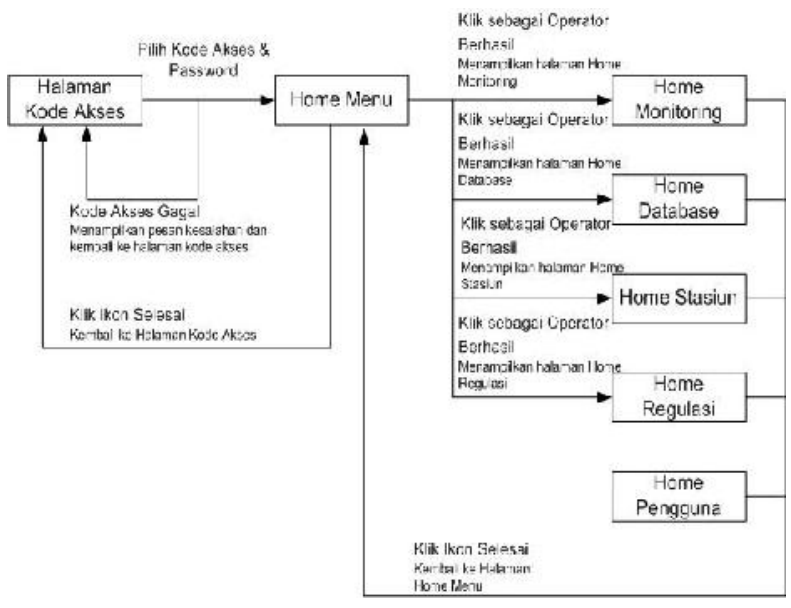

Gambar 20 : STD Login sebagai Operator.

\subsection{Perancangan Layar Software SMS Gateway}

Software SMS Gateway adalah aplikasi yang dikembangkan untuk mengendalikan pengiriman data pengukuran dari data logger dan konfirmasi penerimaannya ke data logger melalui SMS. Berikut ini adalah gambar-gambar rancangan GUI software SMS Gateway yang terdiri dari beberapa tab control.

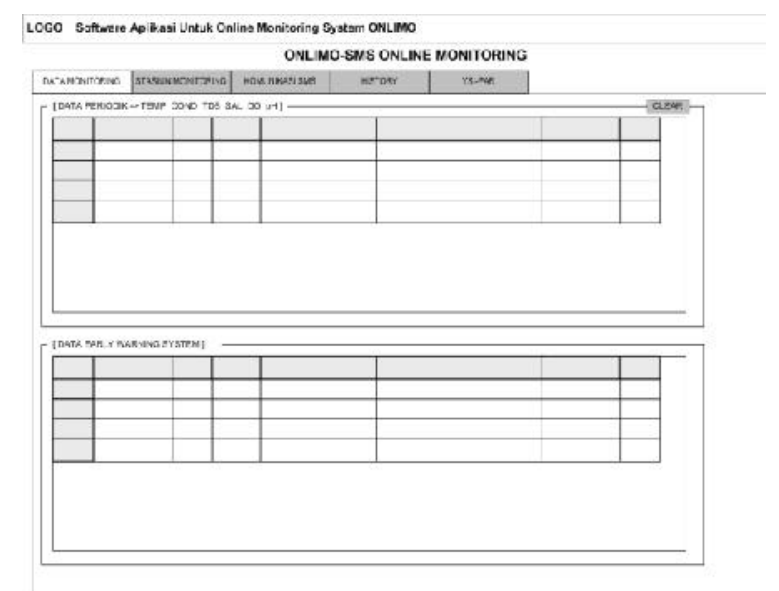

Gambar 21 : Tampilan Tab Control Data Monitoring.

Prosedur untuk menampilkan rancangan window di atas adalah sebagai berikut :

- Jalankan program onlimosmsgw-V2.5.exe $\rightarrow$ Menu ONLIMO SMS ONLINE MONITORING

- Klik DATA MONITORING $\rightarrow$ Tabel Data Periodik Parameter Temperatur, Conductivity, TDS, Salinitas, DO dan pH, dan Tabel Data Early Warning System.

- $\quad$ Klik CLEAR $\rightarrow$ Data Periodik terhapus

Berikut ini adalah tab control Sistem Monitoring, yang dapat ditampilkan dengan cara :

- Klik Stasiun Monitoring $\rightarrow$ Tabel Daftar Stasiun Monitoring, Tabel Daftar Pengguna Informasi Periodik dan Tabel Daftar Pengguna Informasi EWS

- Pada Tabel Daftar Stasiun Monitoring :

- Klik UBAH $\rightarrow$ Isi Telpn No., Lokasi Stasiun, Kode Stasiun dan Keterangan;

- Pada Tabel Daftar Pengguna Informasi Periodik:

- Klik UBAH $\rightarrow$ Isi Telp No., Nama Pengguna, Posisi / Keterangan,

- Klik HAPUS $\rightarrow$ hapus Telp No., Nama Pengguna, Posisi / Keterangan,

- Klik BARU $\rightarrow$ Isi Telp No., Nama Pengguna, Posisi / Keterangan,

- Klik SIMPAN $\rightarrow$ Data tersimpan.

- Pada Tabel Daftar Pengguna Informasi EWS

- Klik UBAH $\rightarrow$ Isi Telp No., Nama Pengguna, Posisi / Keterangan,

- Klik HAPUS $\rightarrow$ hapus Telp No., Nama Pengguna, Posisi / Keterangan,

- Klik BARU $\rightarrow$ Isi Telp No., Nama Pengguna, Posisi / Keterangan,

- Klik SIMPAN $\rightarrow$ Data tersimpan. 


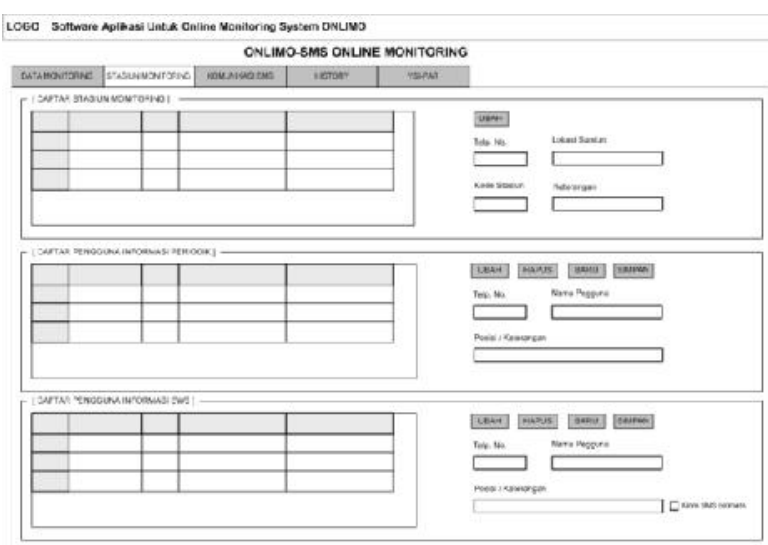

Gambar 22 : Tampilan Tab Control Sistem Monitoring.

Berikut ini adalah tab control komunikasi SMS, yang dapat ditampilkan dengan cara :

- Klik KOMUNIKASI SMS $\rightarrow$ Halaman Stasiun Monitoring, Kontrol Parameter, Lokasi Titik Pantau;

- Pilih Stasiun $\rightarrow$ klik BUKA $\rightarrow$ Informasi data

- Pilih COM $\rightarrow$ klik Modem atau klik Logger

- Ketik di kolom Isi Berita $\rightarrow$ klik SEND SMS

- Klik READ SMS $\rightarrow$ Isi berita

- Isi nomor GSM $\rightarrow$ klik CEK PULSA $\rightarrow$ Muncul sisa pulsa dan masa berlaku

- Klik Data Terakhir $\rightarrow$ Isi tanggal dan Stasiun $\rightarrow$ Temperatur, Kondukstivitas, TDS, Salinitas, DO, $\mathrm{pH}$

- Isi Aki kering $\rightarrow$ Data tegangan aki kering.

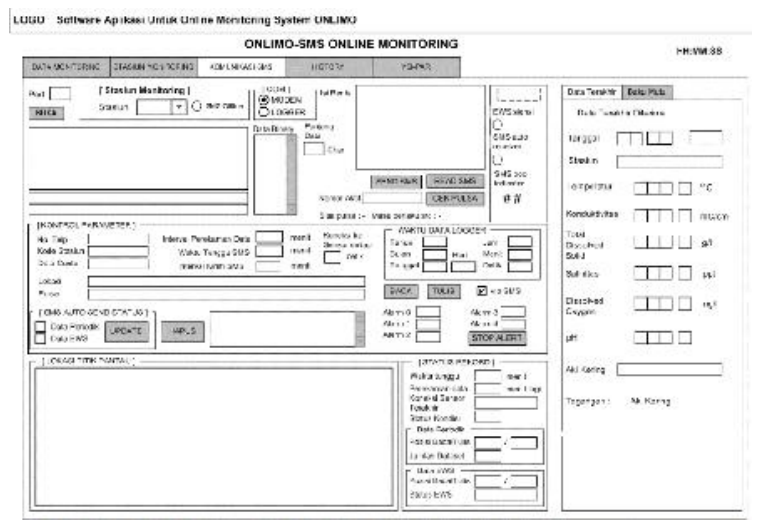

Gambar 23 : Tampilan Tab Control Komunikasi SMS.

- Klik Baku Mutu $\rightarrow$ Data Temperatur, Daya Hantar, Kekeruhan, Kadar Garam, DO, pH, Faktor Koreksi

- Klik Baca $\rightarrow$ komentar

- Tulis komentar $\rightarrow$ Klik Tulis

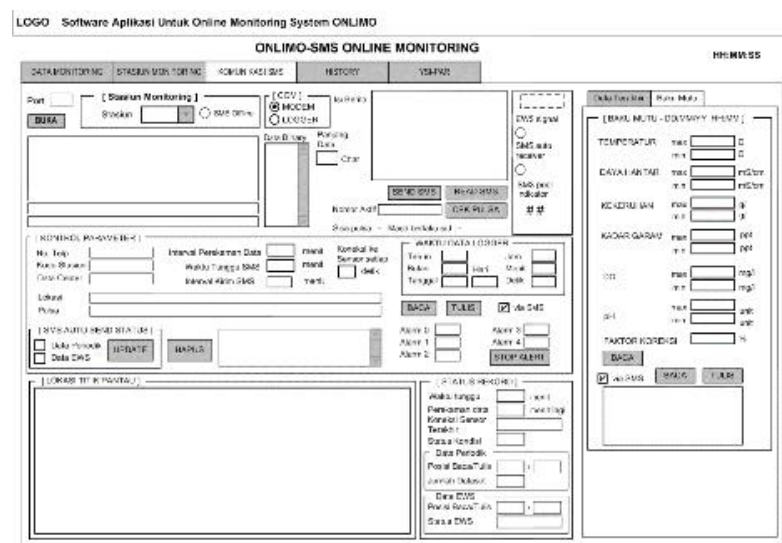

Gambar 24 : Tampilan Tab Control Komunikasi SMS dan Tab Control Baku Mutu.

Berikut ini adalah tab control history, yang dapat ditampilkan dengan cara :

- Klik HISTORY $\rightarrow$ Data Periodik: Temp, Cond, TDS, Sal, DO, pH

- Klik CLEAR $\rightarrow$ Menghapus data Periodik: Temp, Cond, TDS, Sal, DO, pH

- Pilih parameter $\rightarrow$ Klik Query Data $\rightarrow$ Muncul paramater grafik sesuai pilihan

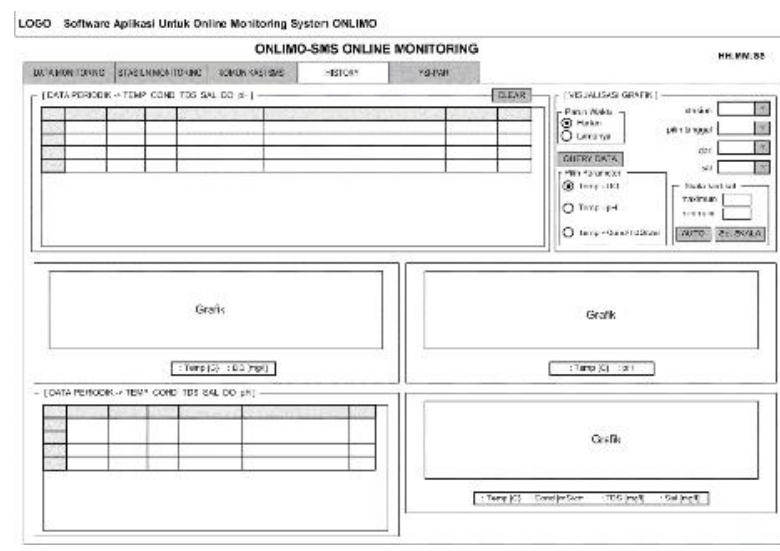

Gambar 25 : Tampilan Tab Control History.

Berikut ini adalah tab control YSI-PAR, yang dapat ditampilkan dengan cara :

- Klik YSI-PAR $\rightarrow$ Setting parameter Data terakhir Diterima, Baudrate, RTDS Operator, Kartu, Status, Modem

- Isi tanggal, Stasiun $\rightarrow$ Klik Stop Kirim SMS Auto 


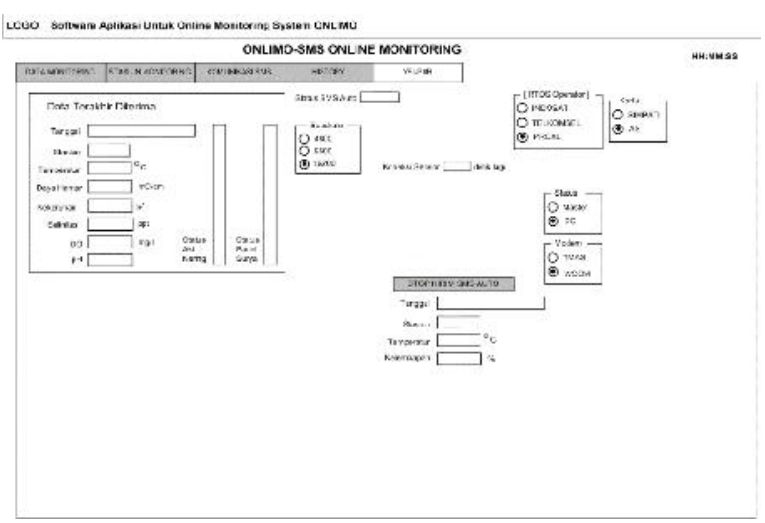

Gambar 26 : Tampilan Tab Control YSI-PAR.

\section{IMPLEMENTASI SISTEM BASIS DATA}

\subsection{Jadwal Implementasi}

Pada pelaksanaan implementasi sistem, diperlukan beberapa langkah yang harus dilakukan sampai implementasi selesai dilakukan. Langkahlangkah tersebut dilaksanakan sesuai jadwal agara implementasi dapat dilakukan dengan efektif dan efisien. Berikut ini jadwal implementasi :

Tabel 10. Jadwal Implementasi.

\begin{tabular}{c|l|c|c|c}
\hline \multirow{2}{*}{ No. } & \multicolumn{1}{|c|}{ Aktivitas } & \multicolumn{3}{c}{ Bulan } \\
\cline { 3 - 5 } & & $\mathbf{1}$ & $\mathbf{2}$ & $\mathbf{3}$ \\
\hline 1 & Persiapan kegiatan & $\mathrm{X}$ & & \\
\hline 2 & Pengumpulan informasi & $\mathrm{X}$ & & \\
\hline 3 & Design basis data & $\mathrm{X}$ & $\mathrm{X}$ & \\
\hline 4 & Design aplikasi & $\mathrm{X}$ & $\mathrm{X}$ & \\
\hline 5 & Pemrograman & & $\mathrm{X}$ & $\mathrm{X}$ \\
\hline 6 & Pembuatan perangkat lunak & & $\mathrm{X}$ & $\mathrm{X}$ \\
\hline 7 & Instalasi perangkat lunak & & & $\mathrm{X}$ \\
\hline 9 & Testing & & & $\mathrm{X}$ \\
\hline 10 & Pelatihan pengguna & & & $\mathrm{X}$ \\
\hline & Evaluasi sistem & & & $\mathrm{X}$ \\
\hline
\end{tabular}

\subsection{Kebutuhan Perangkat Keras}

Sistem basis data ini dapat dikembangkan menjadi basis data berbasis web sehingga tidak membutuhkan resource yang terlalu tinggi. Untuk menjalankan website dibutuhkan perangkat lunak dan perangkat keras yang sesuai agar aplikasi basis data yang telah dibuat dapat bekerja secara optimal. Kebutan perangkat keras dapat dibedakan menjadi dua, yaitu kebutuhan perangkat keras di bagian server dan kebutuhan perangkat keras di bagian client. Berikut adalah tabel kebutuhan minimal perangkat keras di bagian server dan kebutuhan minimal perangkat keras untuk di stasiun RTU (Remote Terminal Unit):
Tabel 11 : Kebutuhan Perangkat Keras Untuk Server.

\begin{tabular}{l|l}
\hline Mainboard & $:$ ASUS \\
\hline Processor & $:$ Intel Core i7 \\
\hline Memory & $:$ 4GB DDR3 \\
\hline Hard Drive & $:$ 1TB HDD \\
\hline CD/DVROM & $:$ DVD $\pm R W$ \\
\hline VGA Card & $:$ NVIDIA GeForce \\
\hline Display & $:$ 22" SVGA LCD Wide Screen \\
\hline
\end{tabular}

Tabel 12 : Kebutuhan minimum Perangkat Keras untuk stasiun RTU.

\begin{tabular}{|c|c|}
\hline \multicolumn{2}{|l|}{ Data logger: } \\
\hline Digital Input ouput & $: 8$ port / 4 port \\
\hline Analog Input & $: 5$ port \\
\hline Flash Memory & : 2 Mbyte \\
\hline Display Data & $\begin{array}{l}: \text { LCD } 2 \times 16 \text { character, LED } \\
\text { Indicator }\end{array}$ \\
\hline Sampling Period & $: 10,15,20,30,60$ detik \\
\hline Sampling Method & $\begin{array}{l}\text { : Komunikasi berbasis } \\
\text { digital sensor serial data } \\
\text { protokol }\end{array}$ \\
\hline Sistem Alarm & : ya \\
\hline Alarm action & : Digital Output, SMS \\
\hline Media Komunikasi & : GSM via Modem \\
\hline Metode Komunikasi & : SMS dua arah \\
\hline Jenis Modem & : Serial GSM/GPRS \\
\hline Clock & : Local RTC \\
\hline Cek Pulsa pra bayar & : Otomatis remote \\
\hline $\begin{array}{l}\text { Jml Sensor } \\
\text { mParameter }\end{array}$ & : 6 - 15 parameter \\
\hline Format Data Sensor & : Floating point \\
\hline Batere / Aki Kering & : 12 VDC, $12 \mathrm{Ah}$ \\
\hline Solar cell panel & $: 50$ WP \\
\hline
\end{tabular}

\subsection{Kebutuhan Perangkat Lunak}

Selain kebutuhan perangkat keras yang harus di perhatikam, kebutuhan lainnya seperti perangkat lunak juga perlu diperhatikan guna menunjang jalannya sistem basis data yang dibuat. Berikut ini adalah kebutuhan perangkat lunak untuk menjalankan aplikasi di bagian server dan RTU:

Tabel 13 : Kebutuhan Perangkat Lunak Server dan RTU.

\begin{tabular}{l|l}
\hline Sistem Operasi & $\begin{array}{l}\text { : Microsoft Windows } \\
\text { 7Profesional }\end{array}$ \\
\hline Aplikasi Database & $\begin{array}{l}\text { : Microsoft Access 2007 } \\
\text { Profesional (Local) }\end{array}$ \\
\hline Aplikasi Server & $\begin{array}{l}\text { : Xampp (Apache Web Server, } \\
\text { MySQL Database Server, PHP) }\end{array}$ \\
\hline Aplikasi RTU & : PHP, PLC Programming \\
\hline
\end{tabular}


Berikut ini adalah beberapa tampilan aplikasi Basis data yang telah dikembangkan.

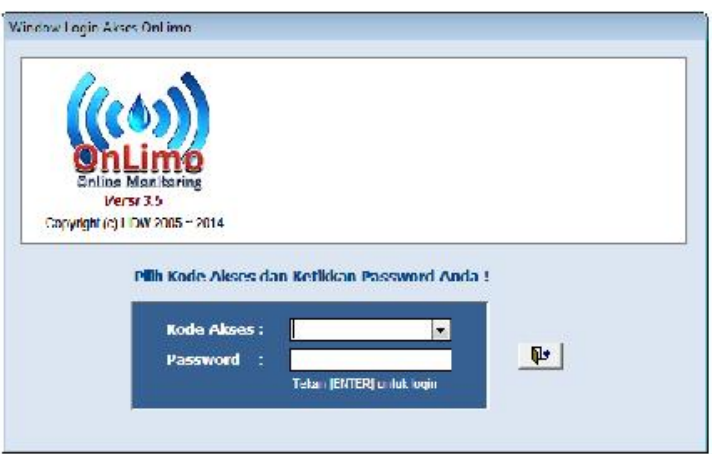

Gambar 27 : Tampilan Untuk Login.

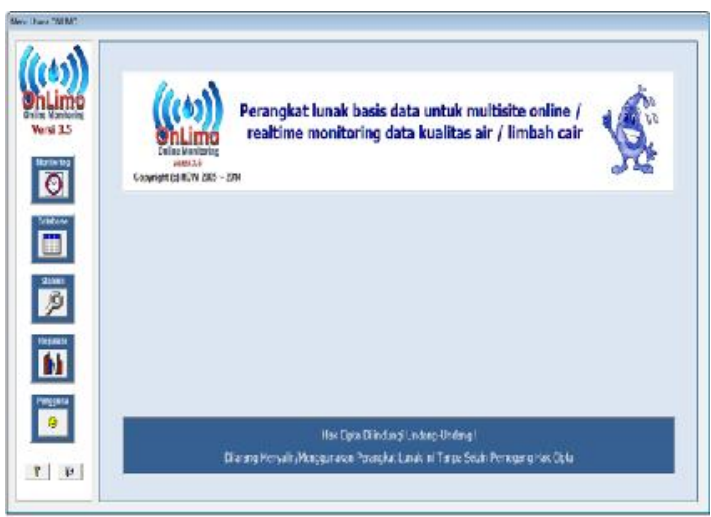

Gambar 28 : Tampilan Menu Utama.

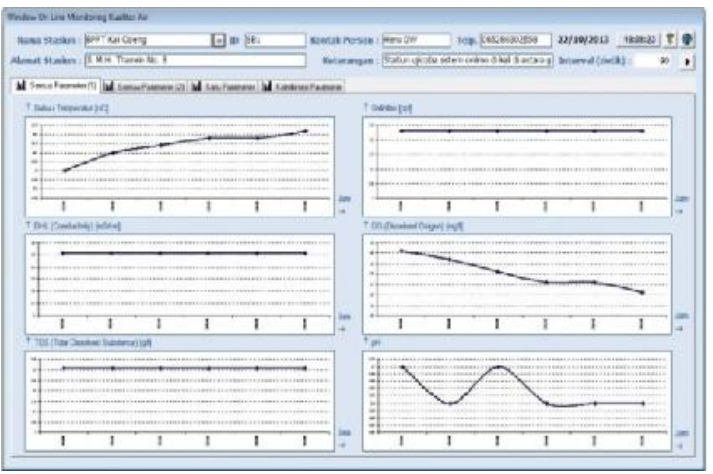

Gambar 29 : Tampilan Grafik 6 Parameter.

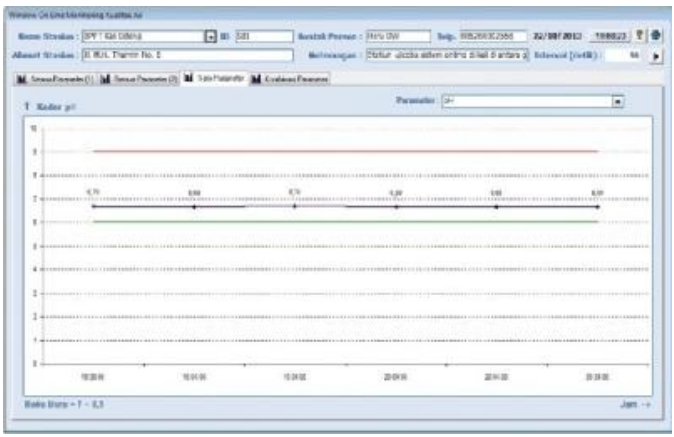

Gambar 30 : Tampilan Grafik Satu Parameter.

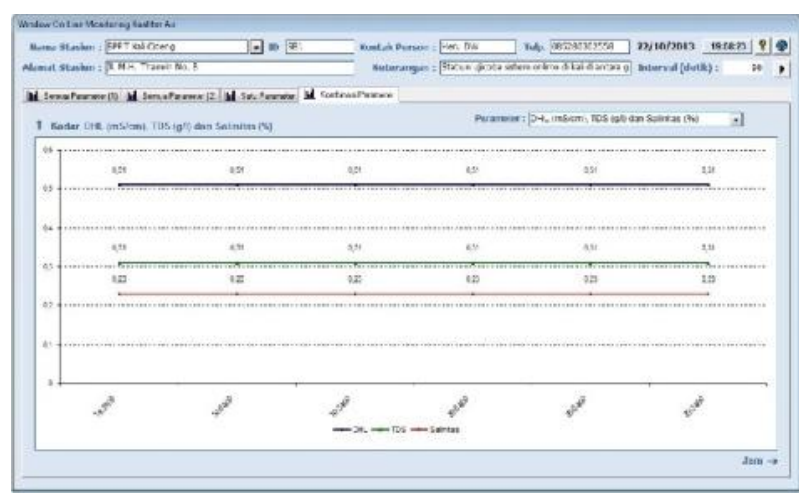

Gambar 31 : Tampilan Grafik Multi Parameter.

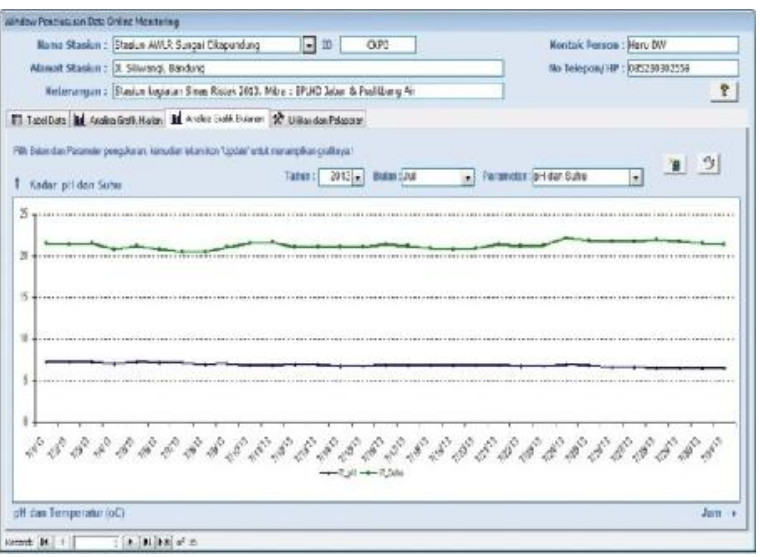

Gambar 32 : Tampilan Analisa Grafik Bulanan.

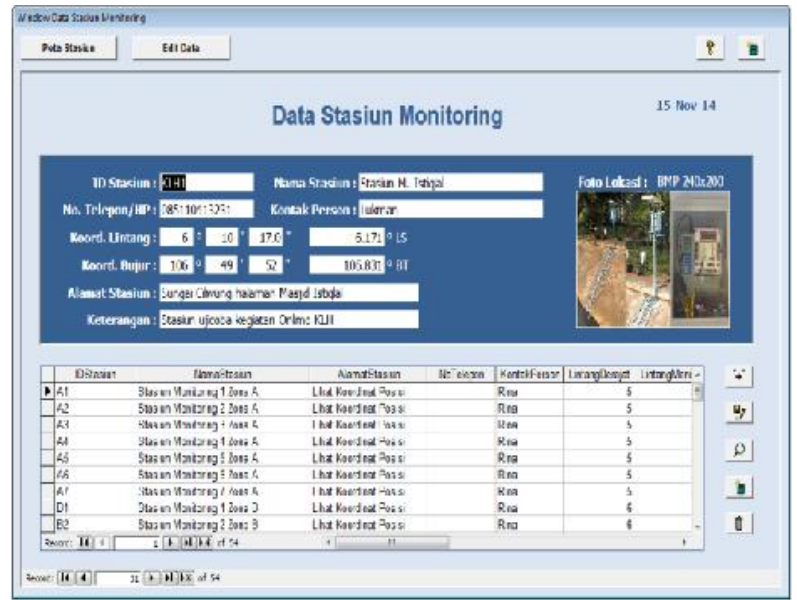

Gambar 33 : Tampilan Data Stasiun monitoring.

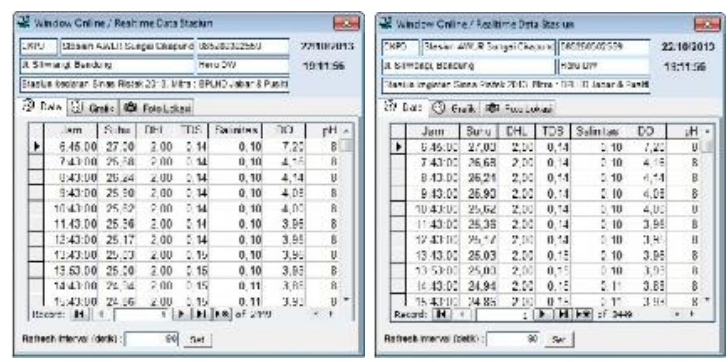

Gambar 34 : Tampilan Data Monitoring. 

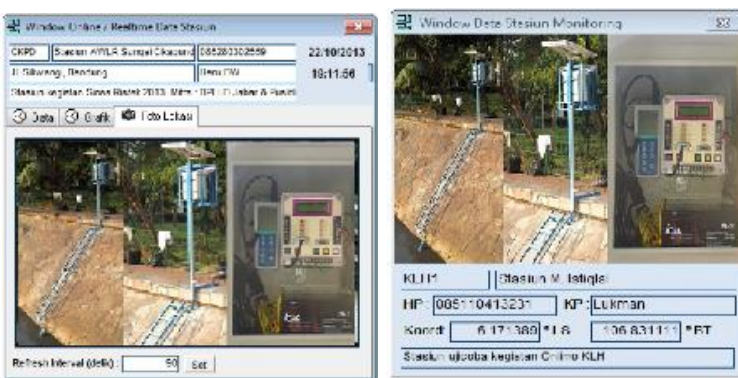

Gambar 35 : Tampilan Data lokasi Stasiun di Masjid Istiqlal.

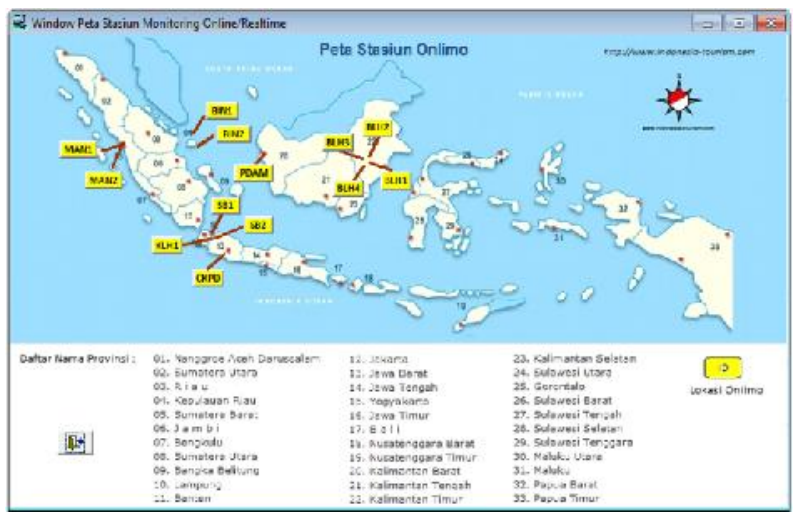

Gambar 36 : Penelusuran Data Monitoring Melalui Window Peta Stasiun Monitoring.

\section{KESIMPULAN}

Dalam merancang sistem basis data online monitoring kualitas air di sungai Ciliwung ini dapat disimpulkan bahwa basis data ini memiliki entitas cukup sederhana yaitu hanya stasiun monitoring, data pengukuran dan user saja.

Sistem perangkat lunak sistem basis data online monitoring yang dirancang memiliki beberapa keunggulan dan fitur-fitur sebagai berikut :

- Sebagian besar petunjuk pengoperasian perangkat lunak ini dibuat dalam Bahasa Indonesia agar mudah dipahami pengguna.

- Proses instalasi perangkat lunak ini sangat mudah, dengan menggunakan prosedur setup program pada umumnya.

- Sistem basis data ini dilengkapi dengan fitur keamanan data, sehingga hanya pengguna yang telah terdaftar saja yang dapat mengoperasikan perangkat lunak ini.

- Sistem basis data ini memiliki user interface untuk input dan edit data-data pemantuan yang mudah digunakan dan dioperasikan.

- Perangkat lunak ini memiliki kemampuan untuk impor dan ekspor data dari dan ke dalam format Microsoft Office.
- Sistem basis data ini memiliki fitur untuk menelusuri dan menampilkan data-data kualitas air sungai Ciliwung dengan cepat serta mencetaknya ke dalam berbagai macam format laporan.

- Perangkat lunak ini dapat menampilkan data dalam bentuk angka dan grafik parameter kualitas air sungai Ciliwung yang telah dianalisa sesuai baku mutu yang digunakan.

- Perangkat lunak ini dapat mengelompokkan file data dan membuat salinan (back-up) file data.

- Perangkat lunak ini dapat mengaktifkan semua user interface baik sebagai window tunggal yang saling terpisah maupun sebagai window yang terintegrasi ke dalam satu menu.

- Informasi data dan grafik tentang kualitas air sungai Ciliwung dalam sistem basis data ini dapat dipublikasikan melalui jaringan internet sehingga dapat dibuka dan diakses kapan dan dimana saja.

- Sistem basis data ini dilengkapi fitur peringatan dini (Early Warning System) apabila ada parameter kualitas air mempunyai eksterim atau nilainys diatas atau dibawah baku mutu.

- Sistem basis data ini dilengkapi dengan petunjuk pengoperasian dan beberapa dokumentasi peraturan serta standar baku mutu baik dalam bentuk cetak maupun elektronik yang siap dibuka kapan saja jika dibutuhkan.

\section{UCAPAN TERIMA KASIH}

Ucapan terima kasih ditujukan kepada Tim Simulasi Model, Pusat Teknologi Lingkungan, BPPT yang telah memberikan data dan bahan untuk mendukung tulisan ini. Tak lupa ucapan terima kasih kepada pihak pengelola Masjid Itiqlal dan Direktorat Pengendalian Pencemaran Air, Ditjen PPKL, KLHK yang telah mendukung dalam mengaplikasikan teknologi Online Monitoring ini.

\section{DAFTAR PUSTAKA}

- Nikmah, S.K., 2010. Studi Sungai Ciliwung: Pengabaian Pemerintah Terhadap Eksistensi Penduduk Pinggir Sungai: Wajah Pengelolaan Sungai Di Indonesia. International NGO Forum on Indonesian Development (INFID).

- Yudo S., Kondisi Kualitas Air Sungai Ciliwung Di Wilayah DKI Jakarta Ditinjau Dari Paramater Organik, Amoniak, Fosfat, Deterjen Dan Bakteri Coli, Jurnal Air Indonesia, Vol. 1, No. 1, 2010.

- Anonim, 2014, Laporan Akhir Pengkajian Penerapan Sistem Monitoring Pengendalian Pencemaran DAS Ciliwung, PUSYANTEK BPPT.

- Yudo S., Manfaat Pemantauan Dalam Bidang Pengelolaan Lingkungan. Jurnal Teknologi Lingkungan, Vol. 1 No. 3, Desember 2000. 
- Connolly, T.M., and Begg C.E. (2010). Basis data Systems: A practical Approach to Design, Implementation, And Management $5^{\text {st }}$ edition. Harlow, England: Addison Wesley.

- Hoffer, J.A. etall, 2002, Modern Systems Analysis And Design. Prentice Hall. UK.

- Wahjono, H.D., S. Yudo, Petunjuk Operasional Software Basis data Multisite Online Monitoring
Kualitas Air di Sungai Tercemar, BPPT, Tahun 2013. Jurnal Air Indonesia, Vol. 1, No. 1, 2010

- Yudo S., Pengembangan Database Pengelolaan Sumberdaya Air untuk Wilayah Kabupaten Pandeglang, Jurnal Air Indonesia, Vol. 7, No. 1, April 2014.

- Wahjono H.D., G. Setiaji, Instalasi Sistem Pemantauan Kualitas Air Online Berbasis GSM di Sungai Ciliwung Segmen Istiqlal. BPPT, 2014. 